\title{
Does Corporate Governance Affect the Financial Performance? Analysis of Findings from Jordanian Banks
}

\author{
Basman Aldalayeen ${ }^{1}$ \\ ${ }^{1}$ Faculty of business administration and economics, Al-hussein Bin Tala University, Jordan \\ Correspondence: Basman Aldalayeen, Faculty of business administration and economics, Al-hussein Bin Tala \\ University, Jordan. E-mail: basman_2014@yahoomail.com
}

Received: February 1, 2017

Accepted: February 26, 2017

Online Published: March 26, 2017

doi:10.5539/ijbm.v12n4p123

URL: https://doi.org/10.5539/ijbm.v12n4p123

\begin{abstract}
The present study explored the impact of corporate governance on the financial performance of selected Jordanian banks. The study is based on secondary data collected from Annual Reports of Companies, research papers, articles and various websites. The sample of the study consists of five banks of Jordan. Multiple regression has been used as the statistical tool to measure the impact of corporate governance on the financial performance of banks under study. Corporate governance score is taken as independent variable while ROA is used as dependent proxy variable of financial performance. The findings of the current research highlighted that corporate governance score has a positive significant impact on the financial performance of Capital Bank of Jordan, Arab Bank, and Bank Al-Etihad. However, significant impact does not found on the financial performance of Jordan Islamic Bank and Jordan Dubai Islamic Bank.
\end{abstract}

Keywords: banks, return on assets, size, sales growth, financial performance, corporate governance

\section{Introduction}

Corporate governance refers to that blend of law, regulation and appropriate voluntary private sector practices which enable the corporation to attract financial and human capital, perform efficiently, and thereby perpetuate itself by generating long-term economic value for its shareholders, while respecting the interests of stakeholders and society as a whole. It ensures that long-term strategic objectives and plans are established and proper management structure regarding organization, systems, and people so that organizational goals and objectives can be achieved. Corporate governance is the term used to describe the way in which companies are directed and controlled. It encompasses issues such as the responsibilities of directors, and the relationships between shareholders, directors and auditors. It can be said to be a structural framework to make a healthy and competitive company which realizes self-cleaning and competitiveness under such strategies, transparency, social orientation, and innovativeness. It is the framework of rules and regulations that enable the stakeholders to exercise appropriate oversight of a company to maximize its value and to obtain a good return on their holdings. The essence of corporate governance is about how owners (principals) of firms can ensure that the firm's assets (and the returns generated by those assets) are used efficiently and in their best interests by managers (agents) delegated with powers to operate those assets. Taking the importance of corporate governance, an attempt has been made by the researcher in this study to examine its impact on the financial performance of selected banks in Jordan.

\section{Literature Review}

Cornett et al. (2009) in the study examined the impact of corporate governance mechanisms on earnings and earnings management in publicly traded bank holding companies in the United States. It has been found that pay-for-performance sensitivity (PPS) and board independence were positively related and the relationship was bidirectional. While both PPS and board independence are associated with higher earnings, their results indicate that more independent boards appear to constrain the earnings management that greater PPS compels. Al-Abbadi and Almbaideen (2010) in the research paper entitled, "Consequences of financial reporting quality on corporate performance. Evidence at the international level" examined the consequences of Financial Reporting Quality (FRQ) on corporate performance in selected industries in Jordan. The author used three proxies of FRQ namely earnings quality, conservatism, and accruals quality. The sample size of the study was 1960 international non-financial listed companies from 25 countries for the period 2002-2010. The use of 
simultaneous equations for the panel data highlighted the positive effect of financial reporting quality (FRQ) on financial performance. This result was robust according to the different measurements of FRQ (earnings quality, accruals quality and accounting conservatism) and for an aggregated measure for the previous three proxies of FRQ. The research showed that this relationship is moderated by the level of corruption perception in the country of origin of the company, the adoption of IFRS, the accounting system used in the country and the influence of the economic cycle. Tyagi (2015) in the study evaluated the impact of corporate governance on the financial performance of Indian IT companies. The sample consists of 20 IT companies listed on NSE Sectoral Index i.e., CNX IT Index. Data was collected from National Stock Exchange (NSE) for the financial year 2012-13 and analyzed with the application of multiple regression. Four corporate governance variables were selected namely: Board Size, Board Independence, CEO Duality, and Audit Committee which were also independent variables in the study. Moreover, the firm's financial performance (ROE) was considered as dependent variable. The findings after regression test revealed that overall corporate governance has a positive impact on the financial performance of selected IT companies in India. Alhroob \& Al-Dalaien (2016) in their research paper investigated the impact of corporate governance on the financial performance of selected banks in Jordan with the application of multiple regression. The results of regression revealed that there is a significant impact of corporate governance score on the financial performance banks under study.

\section{Objective of the Study}

The objective of the research is to explore the impact of corporate governance score on the financial performance of four Jordanian banks namely Jordan Islamic Bank, Capital Bank of Jordan, Jordan Dubai Islamic Bank, Arab Bank, and Bank Al-Etihad.

\section{Hypotheses of the Study}

$\mathrm{Ho}_{1}$ : Corporate governance score has no significant impact on the financial performance of Jordan Islamic Bank.

$\mathrm{Ho}_{2}$ : Corporate governance score has no significant impact on the financial performance of Capital Bank of Jordan.

$\mathrm{Ho}_{3}$ : Corporate governance score has no significant impact on the financial performance of Jordan Dubai Islamic Bank.

$\mathrm{Ho}_{4}$ : Corporate governance score has no significant impact on the financial performance of Arab Bank.

$\mathrm{Ho}_{5}$ : Corporate governance score has no significant impact on the financial performance of Bank Al-Etihad.

\section{Research Methodology}

$>$ Population: The population of the study consists of all banks of Jordan.

$>$ Size of the sample: The size of the sample is five banks of Jordan namely Jordan Islamic Bank, Capital Bank of Jordan, Jordan Dubai Islamic Bank, Arab Bank, and Bank Al-Etihad.

$>$ Collection of Data: The data have been collected through annual reports of the selected banks for the financial years since 2010 to 2015 .

$>$ Statistical Tool: Multiple regression has been used to analyze the results through SPSS.

\section{Hypotheses Testing}

Multiple regression has been applied as the statistical tool to measure the impact of corporate governance score on the financial performance in selected banks. Corporate governance score is independent variable while return on assets (ROA) is used as dependent variable. Firm size, sales growth, and asset tangibility are used as control variables. ROA is used as proxy variable to measure the financial health of selected banks.

Ho $_{1}$ : Corporate governance score has no significant impact on the financial performance of Jordan Islamic Bank.

Table 1. Model Summary of Jordan Islamic Bank

\begin{tabular}{lllll}
\hline Model & R & R Square & Adjusted R Square & Standard Error \\
\hline 1 & 0.894 & 0.837 & 0.802 & 2.664 \\
\hline
\end{tabular}

Predictors: (Constant), Corporate Governance Score.

The null hypothesis is that corporate governance score has no significant impact on the financial performance 
and the alternate states that corporate governance score has a significant impact on the financial performance of Jordan Islamic Bank. Table 1 shows the summary of multiple regression model applied in the study. The value of adjusted $\mathrm{R}$ square is 0.802 which means 80.2 percent variation in ROA (dependent variable) is explained by corporate governance score (independent variable) and rest of the variation is an unexplained variation.

Table 2. Regression coefficients of Jordan Islamic Bank

\begin{tabular}{lllll}
\hline Model-1 & $\begin{array}{l}\text { Standardized } \\
\text { Beta Coefficients }\end{array}$ & Standard Error & t Value & Sig. Value \\
\hline Corporate Governance Score & 0.084 & 1.650 & -6.124 & 0.615 \\
Size & -0.614 & 4.897 & 11.441 & 0.000 \\
Sales Growth & 0.098 & 2.226 & 7.611 & 0.864 \\
Assets Tangibility & -0.529 & 3.097 & 9.334 & 0.007 \\
\hline
\end{tabular}

Dependent Variable: ROA.

Table 2 shows the values of regression coefficients, standard error, $\mathrm{t}$ value and significant value. The standardized beta coefficient gives a measure of contribution of each variable to the model. A larger value indicates that a unit change in the predictor variable has a larger impact on the criterion variable. The results show that Size and Assets Tangibility have negative beta values i.e., -0.614 and -0.529 which indicates negative impact of Size and Asset Tangibility on ROA but they have statistically significant impact $(\mathrm{P}<0.05)$. Besides, the beta value of Sales Growth is positive (0.098) which shows positive impact of Sales Growth on ROA. But, it has insignificant impact on ROA $(\mathrm{P}>0.05)$. However, the value of standardized beta coefficient of corporate governance score is 0.084 (positive) which shows positive impact of corporate governance score on ROA. The above table shows that corporate governance score has statistically insignificant impact on ROA because its $\mathrm{p}$ value is 0.615 which is more than 0.05 at 05 percent level of significance. Therefore, the hypothesis that corporate governance score has no significant impact on the financial performance of Jordan Islamic Bank is accepted.

$\mathrm{Ho}_{2}$ : Corporate governance score has no significant impact on the financial performance of Capital Bank of Jordan.

Table 3. Model Summary of Capital Bank of Jordan

\begin{tabular}{lllll}
\hline Model & R & R Square & Adjusted R Square & Standard Error \\
\hline 2 & 0.841 & 0.786 & 0.761 & 2.844 \\
\hline
\end{tabular}

a. Predictors: (Constant), Corporate Governance Score.

The null hypothesis is that corporate governance score has no significant impact on the financial performance and the alternate states that there is a significant impact of corporate governance score on the financial performance of Capital Bank of Jordan. The researcher has used multiple regression test to evaluate the impact of corporate governance score on the financial performance of Capital Bank of Jordan. Table 3 shows the summary of multiple regression model applied in the study. The value of adjusted $\mathrm{R}$ square is 0.761 which means 76.1 percent variation in ROA (dependent variable) is explained by corporate governance score (independent variable) and rest of the variation $\left(1-R^{2}\right)$ is an unexplained variation in return on assets due to variables that have not been considered in this model.

Table 4. Regression coefficients of capital bank of Jordan

\begin{tabular}{lllll}
\hline Model-2 & $\begin{array}{l}\text { Standardized } \\
\text { Coefficients }\end{array}$ & Beta & & \\
& Standard Error & t Value & Sig. Value \\
\hline Corporate Governance Score & 0.709 & 4.081 & 27.641 & 0.009 \\
Size & -0.681 & 2.306 & -9.043 & 0.000 \\
Sales Growth & 0.397 & 2.418 & -2.227 & 0.002 \\
Assets Tangibility & -0.528 & 3.382 & 13.442 & 0.000 \\
\hline
\end{tabular}

a. Dependent Variable: ROA. 
Table 4 shows the values of regression coefficients, standard error, $t$ value and significant value. Standardized beta coefficient indicates the average change in dependent variable associated with a one unit change in the dependent variable statistically controlling for the other independent variables. The results show that Size and Assets Tangibility have negative beta values i.e., -0.681 and -0.528 which indicates negative impact of Size and Asset Tangibility on ROA but they have statistically significant impact $(\mathrm{P}<0.05)$. Besides, the beta value of Sales Growth is positive (0.107) which shows positive impact of Sales Growth on ROA and it has significant impact on ROA $(\mathrm{P}<0.05)$. However, the value of standardized beta coefficient of corporate governance score is 0.399 (positive) which shows positive impact of corporate governance score on ROA. This impact is statistically significant impact because its $\mathrm{p}$ value is 0.009 which is more than 0.05 at 05 percent level of significance. Therefore, the null hypothesis stands rejected and it can be said that there is a significant impact of corporate governance score on the financial performance of Capital Bank of Jordan.

Ho $_{3}$ : Corporate governance score has no significant impact on the financial performance of Jordan Dubai Islamic Bank.

Table 5. Model summary of Jordan dubai islamic Bank

\begin{tabular}{lllll}
\hline Model & R & R Square & Adjusted R Square & Standard Error \\
\hline 3 & 0.833 & 0.776 & 0.744 & 2.009 \\
\hline
\end{tabular}

Predictors: (Constant), Corporate Governance Score.

The impact of corporate governance score on the financial performance of Jordan Dubai Islamic Bank has been measured with the aid of multiple regression. The null hypothesis is that corporate governance score has no significant impact on the financial performance of Jordan Dubai Islamic Bank and the alternate states that there is a significant impact of corporate governance score on the financial performance of Jordan Dubai Islamic Bank. Table 5 shows the summary of multiple regression model applied in the study. Adjusted R square shows the change in dependent variable (ROA) because of independent variable (corporate governance score). The value of adjusted R square is 0.744 which means 74.4 percent variation in ROA is explained by corporate governance score and rest of the variation $\left(1-R^{2}\right)$ is an unexplained variation in return on assets due to variables that have not been considered in this model.

Table . Regression coefficients of Jordan Dubai Islamic Bank

\begin{tabular}{lllll}
\hline Model-3 & $\begin{array}{l}\text { Standardized } \\
\text { Coefficients }\end{array}$ & Beta & & \\
& 0.077 & Standard Error & t Value & Sig. Value \\
\hline Corporate Governance Score & -0.705 & 3.276 & 33.451 & 0.908 \\
Size & 0.067 & 1.224 & 17.509 & 0.000 \\
Sales Growth & -0.619 & 2.546 & -45.546 & 0.914 \\
Assets Tangibility & & 2.749 & -5.338 & 0.007 \\
\hline
\end{tabular}

a. Dependent Variable: ROA.

Table 6 shows the values of regression coefficients, standard error, $t$ value and significant value. Standardized beta coefficient indicates the average change in dependent variable associated with a one unit change in the dependent variable, statistically controlling for the other independent variables. The results show that Size and Assets Tangibility have negative beta values i.e., -0.705 and -0.619 which indicates negative impact of Size and Asset Tangibility on ROA but they have statistically significant impact $(\mathrm{P}<0.05)$. Besides, the beta value of Sales Growth is positive (0.367) which shows positive impact of Sales Growth on ROA. But it has insignificant impact on ROA ( $P>0.05)$. However, the value of standardized beta coefficient of corporate governance score is 0.077 (positive) which shows positive impact of corporate governance score on ROA. It has statistically insignificant impact on ROA because its $\mathrm{p}$ value is 0.908 which is more than 0.05 at 05 percent level of significance. Therefore, the null hypothesis stands accepted and it can be said that Corporate governance score has no significant impact on financial performance of Jordan Dubai Islamic Bank.

$\mathrm{Ho}_{4}$ : corporate governance score has no significant impact on the financial performance of Arab Bank. 
Table 7. Model Summary of Arab Bank

\begin{tabular}{llllll}
\hline Model & R & R Square & Adjusted R Square & Standard Error & Durbin Watson \\
\hline 4 & 0.866 & 0.829 & 0.809 & 1.297 & 1.677 \\
\hline
\end{tabular}

Predictors: (Constant), Corporate Governance Score.

The null hypothesis is that there is no significant impact of corporate governance score on the financial performance and there is a significant impact of corporate governance score on the financial performance of Arab Bank. Table 7 shows the summary of multiple regression model applied in the study. Adjusted $\mathrm{R}$ square shows the amount of variation in dependent variable (ROA) that is accounted by independent variable (corporate governance score). The value of adjusted $\mathrm{R}$ square is 0.809 which means 80.9 percent variation in ROA is explained by corporate governance score and rest of the variation $\left(1-R^{2}\right)$ is an unexplained variation in return on assets due to variables that have not been considered in this model.

Table 8. Regression coefficients of Arab Bank

\begin{tabular}{|c|c|c|c|c|}
\hline \multirow[t]{2}{*}{ Model-4 } & Standardized & \multicolumn{3}{|l|}{ Beta } \\
\hline & Coefficients & Standard Error & t Value & Sig. Value \\
\hline Corporate Governance Score & 0.617 & 3.083 & 12.647 & 0.000 \\
\hline Size & -0.881 & 2.092 & 2.088 & 0.001 \\
\hline Sales Growth & 0.119 & 1.998 & 4.568 & 0.667 \\
\hline Assets Tangibility & -0.413 & 2.446 & 19.116 & 0.000 \\
\hline
\end{tabular}

a. Dependent Variable: ROA.

Table 8 shows the values of regression coefficients, standard error, $t$ value and significant value. Standardized beta coefficient indicates the average change in dependent variable associated with a one unit change in the dependent variable, statistically controlling for the other independent variables. The results show that Size and Assets Tangibility have negative beta values i.e., -0.881 and -0.413 which indicates negative impact of Size and Asset Tangibility on ROA but they have statistically significant impact $(\mathrm{P}<0.05)$. Besides, the beta value of Sales Growth is positive (0.119) which shows positive impact of sales growth on ROA. But it has insignificant impact on ROA ( $\mathrm{P}>0.05$ ). However, the value of unstandardized beta coefficient of corporate governance score is 0.617 (positive) which shows positive impact of corporate governance score on ROA. This impact is statistically significant because $\mathrm{p}$ value is 0.000 which is less than 0.05 at 05 percent level of significance. Therefore the null hypothesis stands rejected and it can be said that there is a significant impact of corporate governance score on financial performance of Arab Bank.

Ho $_{5}$ : Corporate governance score has no significant impact on the financial performance of Bank Al-Etihad.

Table 9. Model Summary of Bank Al-Etihad

\begin{tabular}{llllll}
\hline Model & R & R Square & Adjusted R Square & Standard Error & Durbin Watson \\
\hline 5 & 0.744 & 0.701 & 0.687 & 2.014 & 1.978 \\
\hline
\end{tabular}

Predictors: (Constant), Corporate Governance Score.

Multiple regression has been applied as the statistical tool to measure the impact of corporate governance score on the financial performance of Bank Al-Etihad. The null hypothesis is that there is no significant impact of corporate governance score on the financial performance and there is a significant impact of corporate governance score on the financial performance of Bank Al-Etihad. Table 9 shows the summary of multiple regression model applied in the study. The value of adjusted $\mathrm{R}$ square is 0.687 which means 80.9 percent variation in ROA (dependent variable) is explained by corporate governance score and rest of the variation $\left(1-\mathrm{R}^{2}\right)$ is an unexplained variation. 
Table 10. Regression coefficients of Bank Al-Etihad

\begin{tabular}{|c|c|c|c|c|}
\hline Model-5 & $\begin{array}{l}\text { Standardized } \\
\text { Coefficients }\end{array}$ & Standard Error & t Value & Sig. Value \\
\hline Corporate Governance Score & 0.542 & 2.741 & 35.551 & 0.0074 \\
\hline Size & -0.729 & 1.974 & 11.452 & 0.001 \\
\hline Sales Growth & 0.138 & 1.227 & -1.556 & 0.852 \\
\hline Assets Tangibility & -0.502 & 2.066 & -8.076 & 0.000 \\
\hline
\end{tabular}

a. Dependent Variable: ROA.

Table 10 shows the values of regression coefficients, standard error, $t$ value and significant value. Standardized beta coefficient indicates the average change in dependent variable associated with a one unit change in the dependent variable, statistically controlling for the other independent variables. The results show that Size and Assets Tangibility have negative beta values i.e., -0.729 and -0.502 which indicates negative impact of Size and Asset Tangibility on ROA but they have statistically significant impact $(\mathrm{P}<0.05)$. Besides, the beta value of Sales Growth is positive (0.138) which shows positive impact of sales growth on ROA. But it has insignificant impact on ROA ( $\mathrm{P}>0.05)$. However, the value of standardized beta coefficient of corporate governance score is 0.542 (positive) which shows positive impact of corporate governance score on ROA. This impact is statistically significant because $\mathrm{p}$ value is 0.0074 which is less than 0.05 at 05 percent level of significance. Therefore the null hypothesis stands rejected and it can be said that there is a significant impact of corporate governance score on financial performance of Bank Al-Etihad.

Table 11. Summary of hypotheses tested

\begin{tabular}{llll}
\hline Hypotheses & P value & Remarks & Results \\
\hline Hypothesis 1 & 0.615 & Insignificant Impact & Accepted \\
Hypothesis 2 & 0.009 & Significant Impact & Rejected \\
Hypothesis 3 & 0.908 & Insignificant Impact & Accepted \\
Hypothesis 4 & 0.000 & Significant Impact & Rejected \\
Hypothesis 5 & 0.0074 & Significant Impact & Rejected \\
\hline
\end{tabular}

\section{Conclusion}

Corporate governance refers to the framework of rules and regulations that enable the stakeholders to exercise appropriate oversight of a company to maximize its value and to obtain a return on their holdings. It refers to that blend of law, regulation and appropriate voluntary private sector practices which enable the corporation to attract financial and human capital, perform efficiently, generates long-term economic value for its shareholders while respecting the interests of stakeholders and society as a whole. It ensures that long-term strategic objectives and plans are established and proper management structure regarding organization, systems, and people so that organizational goals and objectives can be achieved. The current study investigated the impact of corporate governance on the financial performance of Jordan Islamic Bank, Capital Bank of Jordan, Jordan Dubai Islamic Bank, Arab Bank, and Bank Al-Etihad. Multiple regression has been used as the statistical tool for data analysis. Corporate governance score is taken as independent variable while ROA is used as dependent proxy variable of financial performance. Firm size, sales growth, and asset tangibility are used as control variables. The findings explored that there is a significant impact of corporate governance score on the financial performance of Capital Bank of Jordan, Arab Bank, and Bank Al-Etihad. However, the research does not found significant impact on the financial performance of Jordan Islamic Bank and Jordan Dubai Islamic Bank.

\section{References}

Alhroob, M. N. A., \& Al-Dalaien, B. O. A. (2016). Impact of Corporate Governance on the Financial Performance of Selected Jordanian Banks. Golden Research Thoughts, 6(6), 1-10.

Al-Sufy, F. J. et.al. (2013). Corporate Governance and Its Impact on the Quality of Accounting Information in the Industrial Community Shareholding Companies Listed in Amman Financial Market-Jordan. International Journal of Humanities and Social Science, 3(5), 184-189. 
Chalaki, P., Didar, H., \& Riahinezhad, M. (2012). Corporate Governance Attributes and Financial Reporting Quality: Empirical Evidence from Iran. International Journal of Business and Social Science, 3(15), 223-229.

Chen, et al. (2006). Ownership structure, corporate governance, and fraud: Evidence from China, Journal of Corporate Finance, 12, 424-448. https://doi.org/10.1016/j.jcorpfin.2005.09.002

Ehikioya, B. I. (2009). Corporate Governance Structure and Firm Performance in Developing Economies: Evidence from Nigeria. Corporate Governance, 9(3), 231-243. https://doi.org/10.1108/14720700910964307

Fauver, L., \& Fuerst, M. E. (2006). Does Good Corporate Governance Include Employee Representation? Evidence from German Corporate Boards. Journal of Financial Economics, 82(3), 673-710. https://doi.org/10.1016/j.jfineco.2005.10.005

Ginglinger, E., Megginson,W., \& Waxin, T. (2011). Employee Ownership, Board Representation, and Corporate $\begin{array}{lllll}\text { Financial Policies. Journal of Corporate } & \text { Finance, }\end{array}$ https://doi.org/10.1016/j.jcorpfin.2011.03.005

Gull, A. A., Saeed, A., \& Abid, A. (2013). Corporate Governance and Performance: An Empirical Evidence from Textile Sector of Pakistan. African Journal of Business Management, 7(22), 2112-2118.

Ibrahim, Q., Rehman, R., \& Raoof A. (2010). Role of Corporate Governance in Firm Performance: A Comparative Study between Chemical and Pharmaceutical Sector in Pakistan. International Research Journal of Finance and Economics, 50, 8-16.

Kajola, S. O. (2008). Corporate Governance and Firm Performance: The Case of Nigerian Listed Firms. European Journal of Economics, Finance and Administrative Sciences, 14, 16-28.

Mahoney, L., La-Gore, W., \& Scazzero, J. A. (2008). Corporate Social Performance: The financial Performance for Firms that Restate Earnings. Issues in Social and Environmental Accounting, 2(1), 104-130. https://doi.org/10.22164/isea.v2i1.27

Mashayekhi, B., \& Bazaz, M.S. (2008). Corporate Governance and Firm Performance in Iran. Journal of Contemporary Accounting \& Economics, 4(2), 156-172. https://doi.org/10.1016/S1815-5669(10)70033-3

Neifar, S., \& Halioui, K. (2013). Determinants of Corporate Governance Disclosure: The Case of Tunisian Firms Listed on the Tunis Stock Exchange. International Journal of Finance and Accounting, 2(3), 174-183.

Onuorah, A. (2016). Corporate Governance and Financial Reporting Quality in Selected Nigerian Company. International Journal of Management Science and Business Administration, 2(3), 7-16.

Tyagi, N. (2015). Does The Quality of Corporate Governance Affect The Financial Performance In Indian It Sector? An Insight. International Journal of Research in Commerce, Economics and Management, 83-87.

\section{Copyrights}

Copyright for this article is retained by the author(s), with first publication rights granted to the journal.

This is an open-access article distributed under the terms and conditions of the Creative Commons Attribution license (http://creativecommons.org/licenses/by/4.0/). 